\title{
Bacterial endophytes from halophyte black saxaul (Haloxylon aphyllum Minkw.) and their plant growth-promoting properties
}

\author{
Vyacheslav Shurigin ${ }^{1,3 *}$ (D), Begali Alikulov², Kakhramon Davranov³ (D), Zafar Ismailov² \\ ${ }^{1}$ Department of Microbiology and Biotechnology, Faculty of Biology, National University of Uzbekistan, Tashkent, Uzbekistan. \\ ${ }^{2}$ Department of Genetics and Biotechnology, Faculty of Biology, Samarkand State University, Samarkand, Uzbekistan. \\ ${ }^{3}$ Department of Enzymology, Institute of Microbiology, Academy of Sciences of the Republic of Uzbekistan, Tashkent, Uzbekistan.
}

\begin{tabular}{l}
\hline ARTICLE INFO \\
\hline Article history: \\
Received on: August 13, 2021 \\
Accepted on: October 23, 2021 \\
Available online: January 07, 2022 \\
\hline
\end{tabular}

\section{Key words:}

Black saxaul, endophytic bacteria, diversity, plant growth promotion, salinity, cucumber

\begin{abstract}
The purpose of the present research was to study the diversity of bacterial endophytes inhabiting the halophytic plant black saxaul (Haloxylon aphyllum Minkw.). A total of 20 bacterial isolates were isolated from tissues of black saxaul and identified based on their 16S rRNA genes analysis and comparison with the closest relatives registered in GenBank nucleotide data bank from the National Centre for Biotechnology Information. The endophytes were checked for plant growth-promoting activity toward cucumber plants and the strains Bacillus amyloliquefaciens HAPH2, Priestia endophytica HAPH5, Bacillus subtilis HAPH7, Bacillus toyonensis HAPH8, Halomonas sulfidaeris HAPH11, Isoptericola halotolerans HAPH12, Planomicrobium soli HAPH15, and Pseudomonas kilonensis HAPH16 demonstrated high plant growth-promoting activity of cucumber in four soil salinity levels $(0,25,50$, and $100 \mathrm{mM})$ after seeds' inoculation. These bacterial endophytes were able to fix nitrogen, solubilize phosphates, and produce indole-3-acetic acid, 1-aminocyclopropane-1-carboxylate deaminase, and siderophores which are considered as the main plant growth-promoting traits. After field experiments, the best plant growth-promoters can be used as bioinoculants for plants' growth improvement in salinity conditions.
\end{abstract}

\section{INTRODUCTION}

Black saxaul (Haloxylon aphyllum Minkw.) is one of the most well-known desert plants inhabiting the deserts of Uzbekistan, Kazakhstan, and Turkmenistan [1-3].

Saxaul forests perform the following functions in the ecosystem: biomass production, stabilization of sand movement, maintenance of soil layer and specific microclimate, ensuring the growth and development of associated plants (e.g., Carex physodes M. Bieb.), establishment of habitat conditions for animals, and support of permanent microbial communities in the root system and endophytic microorganisms living in plant tissues. Saxaul forests are a source of food for farm animals and a valuable fuel for the local population [4-7].

\footnotetext{
*Corresponding Author

Vyacheslav Shurigin, Department of Microbiology and Biotechnology,

Faculty of Biology, National University of Uzbekistan, Tashkent,

Uzbekistan.E-mail: slaventus87@inbox.ru
}

The tissues of various plants have their own unique communities of bacterial endophytes. There are many reports showing that endophytes play an important role in plant growth stimulation and their protection from phytopathogenic microorganisms [8-13]. Bacterial endophytes have advantages over the bacteria inhabiting the rhizosphere. Once inside the tissue, they have direct contact with the plant, and hence easy communication between cells can take place. Thus, they can have a direct beneficial effect on the host. In this process, compounds produced by bacteria directly affect the physiological activity of a host plant and can increase biomass production [14]. Bacteriogenic substances include indole-3-acetic acid (IAA) [15], siderophores [16], 1-aminocyclopropane-1carboxylate (ACC) deaminase [17], and lytic enzymes, leading to plants beneficial processes such as phosphate solubilization [18], atmospheric nitrogen fixation [19], chelation of metal ions in an absorbable form [16], alleviation of stresses [14,20], and suppression of pathogenic microbiota [21].

Despite the fact that endophytic communities of various plants have been studied, there is still no information about bacterial 
endophytes living in black saxaul and their effect on it. So, this is the first report about bacterial endophytes of black saxaul.

The aim of this study was to isolate and identify bacterial endophytes from roots and stem of black saxaul, as well as check their plant beneficial traits.

\section{MATERIALS AND METHODS}

\subsection{Black Saxaul Plants Collection}

Five plants of black saxaul (H. aphyllum Minkw.) were carefully isolated from the soil of Kyzylkum Desert in Uzbekistan in springtime. The soil particles were eliminated from roots and shoots by washing them in sterile water.

\subsection{Bacteria Isolation}

The shoot and root were cut from each other and the pieces (15 g) were sterilized by putting them into glasses with $99.9 \%$ ethanol for 2 minutes and $10 \%$ sodium hypochlorite for 1 minute. After that, they were put into glasses with sterile water for 2 minutes [22]. The pieces of shoots and roots were longitudinally cut into thin slices. $5 \mathrm{~g}$ of each sample was transferred into tubes with $9 \mathrm{ml}$ of sterile tap water for serial dilution $\left(10^{1}-10^{5}\right) .100 \mu \mathrm{l}$ of suspension from each dilution was transferred and spread on Tryptic Soy Agar. The plates were incubated in a thermostat at $30^{\circ} \mathrm{C}$. In 4 days, the colonies changing in color and shape were transferred and streaked on plates with Tryptic Soy Agar for purification. The pure cultures were used for DNA isolation. We also checked the outer surface of the root and shoot pieces for sterility by putting them onto Tryptic Soy Agar (TSA) media and incubating for 4 days at $30^{\circ} \mathrm{C}$. There were no colonies after incubation.

\subsection{Bacteria Identification}

The method of Dashti et al. [23] was used for bacterial DNA isolation. The bacterial colonies were transferred into Eppendorf tubes with $1 \mathrm{ml}$ of Milli-Q water. The colonies were mixed with water by shaking in hand for 1 minute and incubated at $90^{\circ} \mathrm{C}$ for 20 minutes in a dry block heater. After that, they were centrifuged at 12,000 rpm for 5 minutes. The isolated DNA was visualized using gel electrophoresis.

The extractedDNAwas exposed to 16SrRNAgeneanalysis by means of Polymerase chain reaction (PCR) using the following primers: 27F 5'-GAGTTTGATCCTGGCTCAG-3' (Sigma-Aldrich, St. Louis, MO) and 1492R 5'-GAAAGGAGGTGATCCAGCC-3' (Sigma-Aldrich, St. Louis, MO) [24]. The PCR program was as follows: a primary heating step for 30 seconds at $94^{\circ} \mathrm{C}$, followed by 30 cycles of denaturation for 15 seconds at $94^{\circ} \mathrm{C}$, annealing for 30 seconds at $55^{\circ} \mathrm{C}$, and extension for 1.5 minutes at $68^{\circ} \mathrm{C}$, then followed by the final step for 20 minutes at $68^{\circ} \mathrm{C}$. The PCR products were checked by electrophoresis using GelRed.

The ABI PRISM BigDye 3.1 Terminator Cycle Sequencing Ready Reaction Kit (Applied Biosystems, USA) was used for the sequencing. The obtained sequences were compared with the sequences of the closest relatives from GenBank of the National Centre for Biotechnology Information (NCBI) (http://www.ncbi. nlm.nih.gov/).
The evolutionary history was inferred using the neighbor-joining method [25]. The percentage of replicate trees in which the associated taxa clustered together in the bootstrap test (500 replicates) is shown above the branches [26]. The tree is drawn to scale, with branch lengths in the same units as those of the evolutionary distances used to infer the phylogenetic tree. The evolutionary distances were computed using the maximum composite likelihood method [27] and are in the units of the number of base substitutions per site. This analysis involved 41 nucleotide sequences. All ambiguous positions were removed for each sequence pair (pairwise deletion option). There were a total of 1,648 positions in the final dataset. Evolutionary analyses were conducted in MEGA X [28].

\subsection{Test for Plant Growth Promotion by Bacterial Endophytes}

Isolated bacterial endophytes were cultivated in a nutrient broth medium for 96 hours at $30^{\circ} \mathrm{C}$ and cells concentration was adjusted up to $10^{8} \mathrm{CFU} / \mathrm{ml}$. The seeds of a cucumber (genotype Orzu) were inoculated with bacteria by soaking in bacterial suspension and sown into $500 \mathrm{ml}$ plastic pots containing $400 \mathrm{ml}$ of soil by volume. We specially prepared four types of soil salinity with $\mathrm{NaCl}, 0,25,50$, and $100 \mathrm{mM}$, by watering with water containing the appropriate $\mathrm{NaCl}$ concentration. All pots were set up randomly in five replications for each bacterial strain. Three seeds were sown into each pot. As a control, we used seeds without any inoculation. Plants were grown at $28^{\circ} \mathrm{C}-30^{\circ} \mathrm{C}$ during the day and $18^{\circ} \mathrm{C}-20^{\circ} \mathrm{C}$ at night, and after 14 days, the shoots and roots' dry weight was measured.

\subsection{Tests for Plant-Growth-Promoting Properties}

\subsubsection{IAA production test}

The production of IAA was tested according to the method of Sarwar and Kremer [29]. The bacterial suspension was adjusted to 1 $\times 10^{8} \mathrm{CFU} / \mathrm{ml}$ and added to flasks with $10 \% \mathrm{TSA}$ [30] supplemented with $5 \mathrm{mmol} / \mathrm{l}^{-1}$ of L-tryptophan and cultivated at $30^{\circ} \mathrm{C}$ for 24 hours in the dark. The grown bacteria were centrifuged at $8,000 \times \mathrm{g}$ for 15 minutes and the supernatant was poured into fresh tubes. The Salkowski reagent (mixture of $\mathrm{FeCl}_{3} 0.5 \mathrm{~mol} / 1$ and $\mathrm{H}_{2} \mathrm{SO}_{4} 7.9 \mathrm{~mol} / \mathrm{l}$ ) was added in a 1:1 ratio $(\mathrm{v} / \mathrm{v})$ to the supernatant and left at room temperature for 30 minutes in the dark. The appearance of pink color indicated the production of IAA. For the measurement of IAA, a spectrophotometer at $530 \mathrm{~nm}$ was used. Different concentrations of IAA solutions were used to construct a standard curve.

\subsubsection{Phosphate solubilization test}

The ability of endophytes to solubilize inorganic phosphate was tested according to Mehta and Nautiyal [31]. The bacteria were cultured on solid National Botanical Research Institute's phosphate growth medium (NBRIP) medium (\%): glucose $1, \mathrm{Ca}_{3}\left(\mathrm{PO}_{4}\right)_{2} 0.5$, $\mathrm{MgCl}_{2} 0.5,\left(\mathrm{NH}_{4}\right)_{2} \mathrm{SO}_{4} 0.01, \mathrm{MgSO}_{4} .7 \mathrm{H}_{2} \mathrm{O} 0.025, \mathrm{KCl} 0.02$, and agar 1.5. Plates with bacteria were incubated at $28^{\circ} \mathrm{C}$ for 96 days. The formation of colonies indicated the ability to use inorganic phosphate in the form of $\mathrm{Ca}_{3}\left(\mathrm{PO}_{4}\right)_{2}$ as a sole phosphate source.

\subsubsection{Nitrogen fixation assay}

The colonies of each endophyte were streaked onto solid nitrogendeficient malate medium (g/l): $\mathrm{CaCl}_{2} 0.02, \mathrm{NaCl} 0.1, \mathrm{FeCl}_{3} 0.01$, 
$\mathrm{KH}_{2} \mathrm{PO}_{4} \quad 0.4, \mathrm{~K}_{2} \mathrm{HPO}_{4} \quad 0.5, \mathrm{MgSO}_{4} \cdot 7 \mathrm{H}_{2} \mathrm{O} \quad 0.2, \mathrm{Na}_{2} \mathrm{MoO}_{4} \cdot 2 \mathrm{H}_{2} \mathrm{O}$ 0.002 , sodium malate 5 , agar 15 , and $\mathrm{pH} 7.2-7.4$, supplemented with $50 \mathrm{mg} / \mathrm{l}$ yeast extract. The plates were incubated at $30^{\circ} \mathrm{C}$ for 96 hours and the appearance of growth indicated the ability to fix $\mathrm{N}_{2}$. The newly grown single colonies were streaked onto plates with the same medium to confirm the ability of nitrogen fixation [32].

\subsubsection{Siderophores production test}

Siderophore production was determined by using chrome azurol S (CAS) agar. Isolates were streaked onto CAS agar and incubated at $30^{\circ} \mathrm{C}$ for 96 days. The appearance of an orange halo around the bacterial colony indicated the production of siderophores [33].

\subsubsection{ACC deaminase production test}

The ACC deaminase production by bacteria was tested based on the utilization of ACC as a sole $\mathrm{N}$-source. The endophytes were cultivated on basal medium supplemented with $3.0 \mathrm{mM}$ of ACC. We used $\left(\mathrm{NH}_{4}\right)_{2} \mathrm{SO}_{4}$ as a positive control without adding $\mathrm{N}$-source as a negative [34].

\subsection{Statistical Analysis}

The statistical significance of data was tested by the analysis of variance of the Microsoft Excel 2010 package. Mean comparisons were conducted using the least significant difference test ( $p$ $=0.05)$. The average values of plant growth parameters, IAA production, and the standard deviation were counted based on several replications.

\subsection{Accession Numbers}

The 16S rRNA gene sequences of the endophytic bacteria of H. aphyllum Minkw. were deposited into GenBank under the following accession numbers MZ443974-MZ443993.

\section{RESULTS}

\subsection{Bacterial Endophytes' Identification and Phylogenetic Analysis}

A total of 20 bacterial isolates related to different species were isolated from tissues of roots and shoots of black saxaul. The isolates were identified based on a comparison of their $16 \mathrm{~S}$ rRNA with the closest relatives registered in GenBank. The degrees of their 16S rRNA genes similarities are shown in Table 1.

The percent of identity of $16 \mathrm{~S}$ rRNA gene from black saxaul isolates and the closest relatives from GenBank ranged from 99.38 to 99.79 . The isolates represent three phyla: Firmicutes, Actinobacteria, and Proteobacteria. The most numerous is Firmicutes with 13 representatives: HAPH2, НАРH3, HAPH4, HAPH5, НАРH6, HAPH7, HAPH8, HAPH9, НAPH10, НAPH14, НАРH15, HAPH19, and HAPH20. Among 20 isolates, only 4 were related to Actinobacteria (HAPH1, HAPH12, HAPH13, and HAPH17) and 3

Table 1: Endophytes isolated from black saxaul (H. aphyllum Minkw.) and their closest relatives from GenBank.

\begin{tabular}{|c|c|c|c|c|c|}
\hline \multicolumn{3}{|c|}{ Isolated strains deposited to GenBank } & \multicolumn{3}{|c|}{$\begin{array}{c}\text { Closest match } \\
\text { (16S rRNA genes) (GenBank) }\end{array}$} \\
\hline Strain & Length (bp) & Accession number & Reference strains & $\begin{array}{l}\text { Accession } \\
\text { number }\end{array}$ & $\begin{array}{l}\text { Percent } \\
\text { identity }\end{array}$ \\
\hline HAPH1 & 1481 & MZ443974 & A. agilis & FR682668.1 & 99.66 \\
\hline HAPH2 & 1465 & MZ443975 & B. amyloliquefaciens & LN864483.1 & 99.79 \\
\hline НАРН3 & 1415 & MZ443976 & B. aryabhattai & MN889284.1 & 99.79 \\
\hline HAPH4 & 1456 & MZ443977 & B. cereus & MT538265.1 & 99.66 \\
\hline HAPH5 & 1447 & MZ443978 & Bacillus endophyticus & KR233758.1 & 99.38 \\
\hline HAPH6 & 1486 & MZ443979 & B. pumilus & MN750426.1 & 99.60 \\
\hline HAPH7 & 1463 & MZ443980 & B. subtilis & MT491101.1 & 99.52 \\
\hline HAPH8 & 1411 & MZ443981 & B. toyonensis & MK424259.1 & 99.79 \\
\hline НАРН9 & 1415 & MZ443982 & B. frigoritolerans & LN997924.1 & 99.65 \\
\hline HAPH10 & 1415 & MZ443983 & E. faecalis & LT745973.1 & 99.72 \\
\hline HAPH11 & 1452 & MZ443984 & H. sulfidaeris & MW282893.1 & 99.59 \\
\hline HAPH12 & 1456 & MZ443985 & I. halotolerans & AB489222.1 & 99.66 \\
\hline НАРН13 & 1429 & MZ443986 & K. polaris & MW872360.1 & 99.51 \\
\hline НАРН14 & 1450 & MZ443987 & P. salinarum & МH311999.1 & 99.59 \\
\hline HAPH15 & 1454 & MZ443988 & P. soli & NR_134133.1 & 99.72 \\
\hline НАРН16 & 1466 & MZ443989 & P. kilonensis & LN995719.1 & 99.59 \\
\hline НАРH17 & 1425 & MZ443990 & R. terrae & МH311993.1 & 99.51 \\
\hline HAPH18 & 1446 & MZ443991 & S. tamaricis & MT192575.1 & 99.65 \\
\hline HАPH19 & 1430 & MZ443992 & S. epidermidis & MH118521.1 & 99.65 \\
\hline НАРН20 & 1440 & MZ443993 & S. warneri & MT642942.1 & 99.58 \\
\hline
\end{tabular}




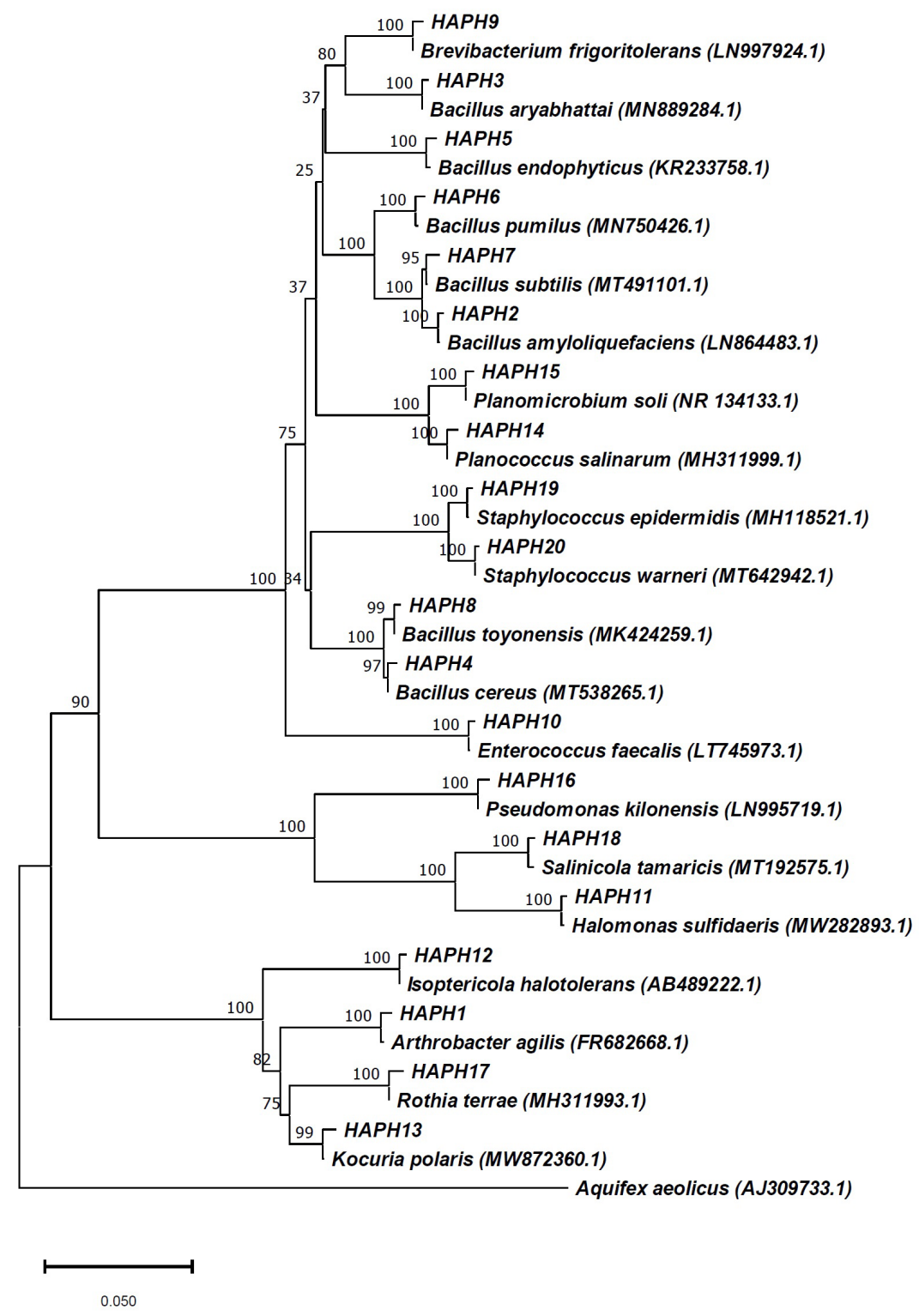

Figure 1: Phylogenetic tree of endophytic bacteria (HAPH1-HAPH20) of black saxaul with its closest relatives registered in GenBank of NCBI.

to Proteobacteria (HAPH11, HAPH16, and HAPH18). The isolates were divided into three classes: Bacilli (13 isolates), Actinobacteria (4 isolates), and Gammaproteobacteria (3 isolates). There were representatives of five orders: Bacillales (12), Micrococcales (4), Lactobacillales (1), Oceanospirillales (2), and Pseudomonadales (1). All isolates were related to 13 genera: Bacillus (HAPH9, HAPH4, HAPH6, HAPH7, HAPH8, and HAPH2), Arthrobacter (HAPH1), Priestia (HAPH3 and HAPH5), Enterococcus (HAPH10), Halomonas (HAPH11), Isoptericola (HAPH12), Kocuria (HAPH13), Planococcus (HAPH14), Planomicrobium (HAPH15), Pseudomonas (HAPH16), Rothia (HAPH17), Salinicola (HAPH18), and Staphylococcus (HAPH19 and HAPH20).

Based on 16S rRNA gene similarities using the neighbor-joining method, the phylogenetic tree was constructed (Fig. 1).

\subsection{Plant Growth-Promotion Activity of Endophytic Bacteria}

The strains of endophytic bacteria were tested for the ability to stimulate plant growth on the example of cucumber. The seeds of cucumber were inoculated with bacterial suspension and cultivated in pots. Although black saxaul is a halophyte, we decided to check whether its endophytes can benefit plants in salinity conditions. That is why for cucumber growing we used four types of soil salinization with $\mathrm{NaCl}: 0,25,50$, and $100 \mathrm{mM}$. We measured shoot and root dry weight as the main growth parameter because the speed of a plant's dry biomass accumulation depends on the speed of cell division and its growth. The results are shown in Table 2.

It can be seen from Table 2 that the majority of endophytes stimulated plant growth of a cucumber less or more actively at different degrees of soil salinity. The strain Bacillus amyloliquefaciens HAPH2 appeared to be the most active plant 

growth-promoting properties 2022;10(01):45-53

growth-promoting bacteria at 0 and $25 \mathrm{mM} \mathrm{NaCl}$ in soil. At $0 \mathrm{mM}$ $\mathrm{NaCl}$, the cucumber seeds' inoculation with this strain resulted in $17.9 \%$ and $18.8 \%$ increase in shoot and root dry weight as compared to the control, respectively. At $25 \mathrm{mM} \mathrm{NaCl}$, the effect of this strain was even more and it increased shoot dry weight up to $22.3 \%$ and root dry weight up to $27.2 \%$ in comparison with the control. At $50 \mathrm{mM} \mathrm{NaCl}$, the strain B. amyloliquefaciens HAPH2 increased cucumber plants shoot dry weight up to $38.1 \%$ and root dry weight up to $37.2 \%$ as compared to the control. At $100 \mathrm{mM} \mathrm{NaCl}$, this strain raised the shoot dry weight up to $65.2 \%$ and root dry weight up to $216.7 \%$. However, at 50 and $100 \mathrm{mM}$ $\mathrm{NaCl}$, the strain $B$. amyloliquefaciens $\mathrm{HAPH} 2$ was less effective than Pseudomonas kilonensis HAPH16. The seeds' inoculation with strain P. kilonensis HAPH16 resulted in $39.9 \%$ and $34.9 \%$ increase in shoot and root dry weight at $50 \mathrm{mM} \mathrm{NaCl}$ as compared to control, respectively. At $100 \mathrm{mM} \mathrm{NaCl}$, P. kilonensis HAPH16 raised the shoot dry weight up to $68.3 \%$ and root dry weight up to $225 \%$. It should be noted that strains Arthrobacter agilis HAPH1, Bacillus cereus HAPH4, Bacillus pumilus HAPH6, Brevibacterium frigoritolerans HAPH9, Kocuria polaris HAPH13, Rothia terrae HAPH17, Staphylococcus epidermidis
HAPH19, and Staphylococcus warneri HAPH20 did not show or showed very low insignificant changes in shoot and root dry weight after seeds' inoculation.

\subsection{Plant Growth-Promoting Traits of Endophytic Bacteria}

The endophytic bacteria were analyzed for their plant growthpromoting characteristics: nitrogen fixation, phosphates solubilization, and production of IAA, ACC deaminase, and siderophores (Table 3).

It can be seen from Table 3 that, from 20 strains, only 5 possessed all checked plant growth-promoting characteristics: B. amyloliquefaciens HAPH2, Priestia endophytica HAPH5, Bacillus subtilis HAPH7, Bacillus toyonensis HAPH8, and P. kilonensis HAPH16. These strains showed $\mathrm{N}_{2}$-fixation, phosphate solubilization, IAA, ACC, deaminase, and siderophores production. The highest amounts of produced IAA were observed in seven strains: B. amyloliquefaciens HAPH2 (172.12 $\mu \mathrm{g} / \mathrm{ml}), P$. endophytica HAPH5 (134.65 $\mu \mathrm{g} / \mathrm{ml})$, B. subtilis HAPH7 (163.86 $\mu \mathrm{g} / \mathrm{ml}), B$. toyonensis HAPH8 (119.03 $\mu \mathrm{g} / \mathrm{ml})$, Isoptericola halotolerans HAPH12 (123.35 $\mu \mathrm{g} / \mathrm{ml})$, Planomicrobium soli

Table 2: Effect of endophytic bacteria from black saxaul on the dry weight of cucumber (Cucumis sativus) (genotype Orzu) plants grown at different concentrations of $\mathrm{NaCl}$ after 14 days of pot experiment.

\begin{tabular}{|c|c|c|c|c|c|c|c|c|}
\hline \multirow{2}{*}{ Bacterial strains } & \multicolumn{2}{|c|}{$0 \mathrm{mM} \mathrm{NaCl}$} & \multicolumn{2}{|c|}{$25 \mathrm{mM} \mathrm{NaCl}$} & \multicolumn{2}{|c|}{$50 \mathrm{mM} \mathrm{NaCl}$} & \multicolumn{2}{|c|}{$100 \mathrm{mM} \mathrm{NaCl}$} \\
\hline & $\begin{array}{l}\text { Shoot dry } \\
\text { weight (g) }\end{array}$ & $\begin{array}{c}\text { Root dry } \\
\text { weight (g) }\end{array}$ & $\begin{array}{l}\text { Shoot dry } \\
\text { weight (g) }\end{array}$ & $\begin{array}{l}\text { Root dry } \\
\text { weight (g) }\end{array}$ & $\begin{array}{l}\text { Shoot dry } \\
\text { weight (g) }\end{array}$ & $\begin{array}{l}\text { Root dry } \\
\text { weight (g) }\end{array}$ & $\begin{array}{l}\text { Shoot dry } \\
\text { weight (g) }\end{array}$ & $\begin{array}{c}\text { Root dry } \\
\text { weight (g) }\end{array}$ \\
\hline $\begin{array}{l}\text { Control (without } \\
\text { inoculation) }\end{array}$ & $4.25 \pm 0.31$ & $1.17 \pm 0.08$ & $3.94 \pm 0.30$ & $1.03 \pm 0.07$ & $3.18 \pm 0.21$ & $0,86 \pm 0.04$ & $2.27 \pm 0.18$ & $0.36 \pm 0.02$ \\
\hline A. agilis HAPH1 & $4.26 \pm 0.31$ & $1.17 \pm 0.08$ & $3.95 \pm 0.30$ & $1.03 \pm 0.07$ & $3.18 \pm 0.21$ & $0.86 \pm 0.04$ & $2.27 \pm 0.18$ & $0.36 \pm 0.02$ \\
\hline $\begin{array}{l}\text { B. amyloliquefaciens } \\
\text { HAPH2 }\end{array}$ & $5.01 \pm 0.42^{\mathrm{a}}$ & $1.39 \pm 0.1$ & $4.82 \pm 0.32$ & $1.31 \pm 0.09$ & $4.39 \pm 0.31$ & $1.18 \pm 0.08$ & $3.75 \pm 0.27$ & $0.78 \pm 0.04$ \\
\hline P. aryabhattai $\mathrm{HAPH} 3$ & $4.37 \pm 0.35$ & $1.21 \pm 0.09$ & $4.26 \pm 0.32$ & $1.13 \pm 0.08$ & $3.82 \pm 0.28$ & $0.92 \pm 0.05$ & $2.58 \pm 0.2$ & $0.53 \pm 0.03$ \\
\hline B. cereus HAPH4 & $4.32 \pm 0.34$ & $1.19 \pm 0.09$ & $4.02 \pm 0.31$ & $1.08 \pm 0.08$ & $3.37 \pm 0.25$ & $0.89 \pm 0.04$ & $2.33 \pm 0.18$ & $0.37 \pm 0.02$ \\
\hline P. endophytica HAPH5 & $4.43 \pm 0.36$ & $1.28 \pm 0.1$ & $4.38 \pm 0.31$ & $1.17 \pm 0.08$ & $4.09 \pm 0.3$ & $0.96 \pm 0.05$ & $2.81 \pm 0.19$ & $0,58 \pm 0.03$ \\
\hline B. pumilus HAPH6 & $4.28 \pm 0.31$ & $1.17 \pm 0.08$ & $4.01 \pm 0.32$ & $1.09 \pm 0.08$ & $3.32 \pm 0.24$ & $0.87 \pm 0.04$ & $2.35 \pm 0.18$ & $0.39 \pm 0.02$ \\
\hline B. subtilis HAPH7 & $4.93 \pm 0.39^{\mathrm{a}}$ & $1.35 \pm 0.1$ & $4.68 \pm 0.37$ & $1.28 \pm 0.09$ & $4.17 \pm 0.31$ & $1.10 \pm 0.07$ & $2.66 \pm 0.2$ & $0.57 \pm 0.03$ \\
\hline B. toyonensis HAPH8 & $4.48 \pm 0.37$ & $1.29 \pm 0.1$ & $4.41 \pm 0.31$ & $1.20 \pm 0.09$ & $4.19 \pm 0.31$ & $1.13 \pm 0.08$ & $3.25 \pm 0.23$ & $0.75 \pm 0.04$ \\
\hline $\begin{array}{l}\text { B. frigoritolerans } \\
\text { HAPH9 }\end{array}$ & $4.25 \pm 0.31$ & $1.17 \pm 0.08$ & $3.94 \pm 0.31$ & $1.03 \pm 0.07$ & $3.18 \pm 0.2^{`} 1$ & $0.86 \pm 0.04$ & $2.27 \pm 0.18$ & $0.36 \pm 0.02$ \\
\hline E. faecalis HAPH10 & $4.38 \pm 0.35$ & $1.22 \pm 0.1$ & $4.10 \pm 0.30$ & $1.11 \pm 0.08$ & $3.56 \pm 0.26$ & $0.94 \pm 0.05$ & $2.31 \pm 0.18$ & $0.37 \pm 0.02$ \\
\hline H. sulfidaeris HAPH11 & $4.41 \pm 0.37$ & $1.26 \pm 0.1$ & $4.19 \pm 0.31$ & $1.14 \pm 0.08$ & $3.86 \pm 0.29$ & $0.95 \pm 0.05$ & $2.88 \pm 0.19$ & $0.61 \pm 0.03$ \\
\hline $\begin{array}{l}\text { I. halotolerans } \\
\text { HAPH12 }\end{array}$ & $4.43 \pm 0.36$ & $1.27 \pm 0.1$ & $4.31 \pm 0.32$ & $1.16 \pm 0.08$ & $4.07 \pm 0.3$ & $0.98 \pm 0.05$ & $3.12 \pm 0.21$ & $0.60 \pm 0.03$ \\
\hline K. polaris HAPH13 & $4.26 \pm 0.31$ & $1.18 \pm 0.09$ & $3.87 \pm 0.29$ & $0.82 \pm 0.05$ & $3.33 \pm 0.23$ & $0.79 \pm 0.04$ & $2.21 \pm 0.18$ & $0.34 \pm 0.02$ \\
\hline P. salinarum НAPH14 & $4.39 \pm 0.32$ & $1.23 \pm 0.09$ & $4.08 \pm 0.31$ & $1.10 \pm 0.08$ & $3.65 \pm 0.26$ & $0.94 \pm 0.05$ & $2.61 \pm 0.19$ & $0.56 \pm 0.03$ \\
\hline P. soli HAPH15 & $4.52 \pm 0.37$ & $1.32 \pm 0.1$ & $4.45 \pm 0.37$ & $1.23 \pm 0.09$ & $4.31 \pm 0.32$ & $1.09 \pm 0.06$ & $3.65 \pm 0.24$ & $0.70 \pm 0.04$ \\
\hline P. kilonensis HAPH16 & $4.73 \pm 0.38$ & $1.34 \pm 0.1$ & $4.61 \pm 0.36$ & $1.28 \pm 0.1$ & $4.45 \pm 0.36$ & $1.16 \pm 0.07$ & $3.82 \pm 0.29$ & $0.81 \pm 0.05$ \\
\hline R. terrae HAPH17 & $4.29 \pm 0.31$ & $1.18 \pm 0.08$ & $3.96 \pm 0.30$ & $0.83 \pm 0.05$ & $3.18 \pm 0.21$ & $0.76 \pm 0.04$ & $2.27 \pm 0.17$ & $0.49 \pm 0.03$ \\
\hline S. tamaricis HAPH18 & $4.38 \pm 0.32$ & $1.23 \pm 0.09$ & $4.17 \pm 0.31$ & $1.11 \pm 0.08$ & $3.76 \pm 0.28$ & $0.96 \pm 0.05$ & $2.64 \pm 0.19$ & $0.68 \pm 0.03$ \\
\hline S. epidermidis HAPH19 & $4.25 \pm 0.30$ & $1.17 \pm 0.08$ & $3.94 \pm 0.3$ & $1.03 \pm 0.07$ & $3.18 \pm 0.21$ & $0,86 \pm 0.04$ & $2.27 \pm 0.18$ & $0.36 \pm 0.02$ \\
\hline S. warneri HAPH 20 & $4.32 \pm 0.31$ & $1.19 \pm 0.08$ & $3.99 \pm 0.3$ & $1.07 \pm 0.07$ & $3.49 \pm 0.25$ & $0.92 \pm 0.05$ & $2.31 \pm 0.19$ & $0.45 \pm 0.03$ \\
\hline
\end{tabular}

${ }^{a}$ Statistically significant at $p \leq 0.05$. 
Table 3: Plant growth-promoting properties of the isolated endophytes.

\begin{tabular}{|c|c|c|c|c|c|}
\hline Bacterial strains & $\mathrm{N}_{2}$-fixation & IAA $(\mu \mathrm{g} / \mathrm{ml})$ & $\begin{array}{l}\text { Phosphates } \\
\text { solubilization }\end{array}$ & $\begin{array}{c}\text { ACC } \\
\text { deaminase }\end{array}$ & $\begin{array}{c}\text { Siderophores } \\
\text { production }\end{array}$ \\
\hline A. agilis HAPH1 & - & $18.74 \pm 2.16$ & - & - & - \\
\hline B. amyloliquefaciens HAPH2 & + & $172.12 \pm 5.25^{\mathrm{a}}$ & + & + & + \\
\hline P. aryabhattai HAPH3 & - & $26.85 \pm 2.51$ & + & - & + \\
\hline B. cereus HAPH4 & - & $21.23 \pm 3.84$ & - & - & - \\
\hline P. endophytica HAPH5 & + & $134.65 \pm 5.11$ & + & + & + \\
\hline B. pumilus HAPH6 & - & $17.17 \pm 2.98$ & + & - & - \\
\hline B. subtilis HAPH7 & + & $163.86 \pm 4.73$ & + & + & + \\
\hline B. toyonensis $\mathrm{HAPH} 8$ & + & $119.03 \pm 5.82^{\mathrm{a}}$ & + & + & + \\
\hline B. frigoritolerans HAPH9 & - & $31.56 \pm 4.67$ & - & - & - \\
\hline E. faecalis HAPH10 & - & $48.31 \pm 3.73$ & - & - & - \\
\hline H. sulfidaeris HAPH11 & - & $96.78 \pm 4.29$ & + & - & + \\
\hline I. halotolerans HAPH12 & - & $123.35 \pm 4.58$ & + & + & - \\
\hline K. polaris HАРН13 & - & $15.06 \pm 2.17$ & - & - & - \\
\hline P. salinarum HAPH14 & - & $65.91 \pm 3.42$ & - & + & + \\
\hline P. soli HAPH15 & - & $141.32 \pm 4.63$ & + & + & - \\
\hline P. kilonensis HAPH16 & + & $159.47 \pm 4.24$ & + & + & + \\
\hline R. terrae HAPH17 & - & $41.31 \pm 3.11$ & - & - & - \\
\hline S. tamaricis HAPH18 & - & $17.69 \pm 3.85$ & - & - & - \\
\hline S. epidermidis HAPH19 & - & $23.84 \pm 2.59$ & - & - & - \\
\hline S. warneri $\mathrm{HAPH} 20$ & - & $31.99 \pm 3.14$ & + & - & + \\
\hline
\end{tabular}

${ }^{a}$ Statistically significant at $p \leq 0.05$.

HAPH15 $(141.32 \mu \mathrm{g} / \mathrm{ml})$, and P. kilonensis HAPH16 (159.47 $\mu \mathrm{g}$ / $\mathrm{ml})$. The following eight strains did not have any of the checked traits and the IAA level was too low: $S$. epidermidis HAPH19, $B$. cereus HAPH4, B. frigoritolerans HAPH9, Enterococcus faecalis HAPH10, K. polaris HAPH13, R. terrae HAPH17, Salinicola tamaricis HAPH18, and A. agilis HAPH1. Four strains possessed three important characteristics: $P$. soli HAPH15, I. halotolerans HAPH12, Planococcus salinarum HAPH14, and Halomonas sulfidaeris HAPH11. The strains Priestia aryabhattai HAPH3 and $S$. warneri HAPH 20 could solubilize phosphates and produce siderophores, but their IAA production was insignificant. The strain B. pumilus HAPH6 could only solubilize phosphate.

\section{DISCUSSION}

As a result of the conducted research, we isolated 20 different species of endophytic bacteria from black saxaul. These bacteria are related to 3 phyla, 3 classes, 5 orders, 8 families, and 13 genera. Some of them demonstrated high plant growth-promoting activity in the stimulation of a cucumber plant's growth. To explain the activity, we conducted tests for some important plant growth-promoting traits. There were many reports about plant growth-promoting properties of endophytic bacteria isolated from different plants $[8,13,35]$.

In our research, the strains $B$. amyloliquefaciens HAPH2, $P$. endophytica HAPH5, B. subtilis HAPH7, B. toyonensis HAPH8, $H$. sulfidaeris HAPH11, I. halotolerans HAPH12, P. soli HAPH15, and P. kilonensis HAPH16 showed the highest plant growth-promoting activity. Gamez et al. [36] reported on B. amyloliquefaciens Bs006 which was selected after screening as one of the best plant growthpromoting rhizobacteria. The strain promoted banana growth on the same level as chemical fertilization and was proposed to be used as a formulation of a new biofertilizer. Park et al. [37] reported on Bacillus aryabhattai SRB02 (now P. endophytica) isolated from the rhizosphere of soybean which significantly promoted the growth of rice and soybean by producing phytohormones. There were especially many reports about different strains of endophytic $B$. subtilis isolated from Camellia oleifera [38], Theobroma cacao L. [39], and Zea mays [40] and their antimicrobial and plant growthpromoting properties. The endophytic bacteria $B$. toyonensis COPE52 stimulated shoot and root length and increased biomass and chlorophyll content of blueberry plants (Vaccinium spp. var. Biloxi) [41]. The bacteria H. sulfidaeris HAPH11, I. halotolerans HAPH12, and $P$. soli HAPH15 are considered halotolerant. Zhou et al. [42] studied the effect of halotolerant rhizobacteria isolated from halophytes on the growth of sugar beet under salt stress and observed growth stimulation activity of some bacterial strains. However, they did not find plant growth-promoting activity in strain I. halotolerans TGT-T12. Shurigin et al. [13] also isolated endophytic strains $H$. sulfidaeris JST7 and $P$. soli JST11 from halophyte Seidlitzia rosmarinus Ehrenb. ex Boiss. The strains did not show any plant growth-promoting (PGP) activity. Egamberdieva et al. [11] reported on antibacterial and antifungal efficacy of endophytic $P$. kilonensis isolated from horseradish (Armoracia rusticana G. Gaertn., B. Mey. \& Scherb.). Due to its antimicrobial properties, P. kilonensis could protect plants against microbial diseases.

The endophytic bacteria from black saxaul were tested for plant growth-promoting properties. The strains $B$. amyloliquefaciens 

growth-promoting properties 2022;10(01):45-53

HAPH2, P. endophytica HAPH5, B. subtilis HAPH7, B. toyonensis HAPH8, H. sulfidaeris HAPH11, I. halotolerans HAPH12, P. soli HAPH15, and P. kilonensis HAPH16, which showed high plant stimulatory activity, were positive in a minimum of three of five tests for plant growth-promoting properties : nitrogen fixation, phosphates solubilization, and production of IAA, ACC deaminase, and siderophores. Nitrogen $(\mathrm{N})$ is one of the most important chemical elements for plants growth and an essential component of all enzymes and proteins, nucleic acids of DNA, and chlorophyll [43]. In the form of $\mathrm{N}_{2}$, it is a very stable and inert gas that does not come into reactions. However, rhizospheric and endophytic bacteria can converse $\mathrm{N}_{2}$ into ammonia which easily dissolves in water and directly feed a plant [44]. Muangthong et al. [45] reported on the isolation and characterization of endophytic nitrogen-fixing bacteria from sugarcane. Potassium also is one of the most important nutrients for plant growth. Some endophytes produce organic acids which can be excreted into soil and convert phosphate complexes into orthophosphates for plant absorption and usage. Thus, such endophytic phosphates solubilizing bacteria were proposed for usage as biofertilizers [46]. IAA is related to phytohormones, which stimulates seed germination, increases the root system, and regulates biosynthesis of metabolites and resistance to extreme conditions like salt and drought stresses [47]. Endophytes due to the production of IAA can stimulate plant root growth through supplying the plant with more nutrients from soil [48].

In our research, the cucumber plants grown at different $\mathrm{NaCl}$ concentrations and seeds' inoculation with some endophytes resulted in higher shoot and root dry mass as compared to control plants. The endophytes $P$. kilonensis HAPH16, P. endophytica HAPH5, B. subtilis HAPH7, B. toyonensis HAPH8, I. halotolerans HAPH12, $P$. salinarum HAPH14, $P$. soli HAPH15, and $B$. amyloliquefaciens HAPH2 produced ACC deaminase. Ethylene is a hormone which is overproducing in plants in stress conditions like high or low-temperature stresses, high salt concentration, drought, flooding, and so on. In such conditions, ethylene production leads to defoliation, fastened vegetation period, and decrease of plant growth and leads to yield lowering. 1-Aminocyclopropane-1carboxylic acid (ACC) is an ethylene precursor and the enzyme ACC deaminase is involved in plant growth promotion through cleavage of ACC and lowering of ethylene level in the plant. The lower the ethylene level, the lower the stress in the plant in stress conditions. In this way, ACC deaminase-producing bacteria can stimulate plant growth in stress conditions like high salt concentration [49].

The bacteria $S$. warneri HAPH20, P. aryabhattai HAPH3, $P$. endophytica HAPH5, B. subtilis HAPH7, B. toyonensis HAPH8, $H$. sulfidaeris HAPH11, P. salinarum HAPH14, $P$. kilonensis HAPH16, and B. amyloliquefaciens HAPH2 produced siderophores. Yadav [46] reported that endophytes that produce siderophores can make iron available for the plant through iron chelating that is especially important for plants growing in irondeficient soils. Siderophores production by bacteria is one of the important mechanisms of plant pathogenic fungi biocontrol [50].

The above-stated data reported by different scientists about various mechanisms of plant growth promotion explain why some of the endophytes from black saxaul can stimulate the growth of cucumber plants in salt stress conditions.

\section{CONCLUSION}

The strains B. amyloliquefaciens HAPH2, P. endophytica HAPH5, B. subtilis HAPH7, B. toyonensis HAPH8, H. sulfidaeris HAPH11, I. halotolerans HAPH12, P. soli HAPH15, and P. kilonensis HAPH16 isolated from tissues of black saxaul demonstrated a high plant growth-promoting activity of cucumber in four soil salinity levels $(0,25,50$, and $100 \mathrm{mM})$ after seeds' inoculation. It can be explained that salt-tolerant bacteria can live inside halophytic plants, which do not lose their activity in high salt concentrations. These strains were able to fix nitrogen, solubilize phosphates, and produce IAA, ACC deaminase, and siderophores which are considered as the main plant growth-promoting traits. After field experiments, the best plant growth promoters can be used as bioinoculants for plants growth improvement in soil salinity conditions.

\section{AUTHORS' CONTRIBUTION}

VS and BA carried out the experiments. VS analyzed data. BA statistically analyzed results. KD and VS wrote the draft of the manuscript. KD conducted the critical revision of the manuscript. ZI worked out the concept and design and supervised and funded the experiments. All the authors contributed equally to this manuscript and agreed to submit it for publication.

\section{FUNDING}

There is no funding to report.

\section{CONFLICTS OF INTEREST}

The authors report no financial or any other conflicts of interest in this work.

\section{ETHICAL APPROVALS}

This study does not involve experiments on animals or human subjects.

\section{PUBLISHER'S NOTE}

This journal remains neutral with regard to jurisdictional claims in published institutional affiliation.

\section{REFERENCES}

1. Shuyskaya EV, Gismatullina LG, Toderich KH, Voronin PY, Soldatova NV. Genetic differentiation of black saxaul, Haloxylon aphyllum (Chenopodiaceae), along a soil salinity gradient in the Kyzylkum desert. Russ J Ecol 2012;43(4):302-6.

2. Zhaglovskaya AA, Aidosova SS, Akhtayeva NZ, Mamurova AT, Yessimova DD, Azhaev GS. Anthropogenic impacts on population structure and floristic composition of black saxaul (Haloxylon aphyllum Minkw.) woodlands in Ili Delta region, Kazakhstan. Ecol Environ Conserv 2016;22(3):1565-75.

3. Fedorovich BA, Babaev AG, Owen L. Karakum desert. Encyclopedia Britannica. 2018. Available via https://www.britannica.com/place/ Karakum-Desert.

4. Buras A, Wucherer W, Zerbe S, Noviskiy Z, Muchitdinov N. Allometric variability of Haloxylon species in Central Asia. Ecol Manage 2012;274:1-9.

5. Gintzburger G, Toderich KN, Mardonov BK, Makhmudov MM. Rangelands of the arid and semi-arid zones in Uzbekistan. Montpellier 
(France) CIRAD/ICARDA: Centre de Cooperation Internationale en Resherche Agronomique pour le Development (CIRAD), 2003.

6. Pyankov VI, Black CC, Artyusheva EG, Voznesenskaya EV, Ku MSB, Edwards G. Features of photosynthesis in Haloxylon species of Chenopodiaceae that are dominant plants in Central Asia deserts. Plant Cell Physiol 1999;40:125-34.

7. Toderich KN, Shuyskaya EV, Ismail S, Gismatullina LG, Radjabov $\mathrm{T}$, Bekchanov $\mathrm{BB}$, et al. Phytogenic resources of halophytes of Central Asia and their role for rehabilitation of sandy desert degraded rangelands. J Land Degrad Dev 2009;20(4):386-96.

8. Hassan SED. Plant growth-promoting activities for bacterial and fungal endophytes isolated from medicinal plant of Teucrium polium L. J Adv Res 2017;8(6):687-95.

9. Pham VT, Rediers H, Ghequire MG, Nguyen HH, De Mot R, Vanderleyden $\mathrm{J}$, et al. The plant growth-promoting effect of the nitrogen-fixing endophyte Pseudomonas stutzeri A15. Arch Microbiol 2017;199(3):513-7; http://doi.org/10.1007/s00203-016-1332-3

10. Egamberdieva D, Shurigin V, Alaylar B, Wirth S, BellingrathKimura SD. Bacterial endophytes from horseradish (Armoracia rusticana G. Gaertn., B. Mey. \& Scherb.) with antimicrobial efficacy against pathogens. Plant Soil Environ 2020;66:309-16; http://doi. org $110.17221 / 137 / 2020-P S E$

11. Egamberdieva D, Shurigin V, Alaylar B, Ma H, Müller MEH, Wirth $\mathrm{S}$, et al. The effect of biochars and endophytic bacteria on growth and root rot disease incidence of Fusarium infested narrow-leafed lupin (Lupinus angustifolius L.). Microorganisms 2020;8:496; http://doi. org/10.3390/microorganisms8040496

12. Shurigin V, Egamberdieva D, Samadiy S, Mardonova G, Davranov $\mathrm{K}$. Endophytes from medicinal plants as biocontrol agents against Fusarium caused diseases. Microbiol J 2020;82(4):41-52; http://doi. org/10.15407/microbiolj82.04.041

13. Shurigin V, Egamberdieva D, Li L, Davranov K, Panosyan H, Birkeland NK, et al. Endophytic bacteria associated with halophyte Seidlitzia rosmarinus Ehrenb. ex Boiss. from arid land of Uzbekistan and their plant beneficial traits. J Arid Land 2020;12:730-40; http:// doi.org/10.1007/s40333-020-0019-4

14. Jayakumar A, Kumar VP, Joseph M, Nair IC, Remakanthan A, Radhakrishnan EK. 3 - Plant growth-promoting mechanisms of endophytes. In: Kumar A, Radhakrishnan EK (eds.). Microbial Endophytes, Woodhead Publishing, pp 57-74, 2020; http://doi. org/10.1016/B978-0-12-819654-0.00003-X

15. Abedinzadeh M, Etesami H, Alikhani HA. Characterization of rhizosphere and endophytic bacteria from roots of maize (Zea mays L) plant irrigated with wastewater with biotechnological potential in agriculture. Biotechnol Rep 2019;21:e00305; http://doi.org/10.1016/j. btre.2019.e00305

16. Jasim B, John Jimtha C, Jyothis M, Radhakrishnan EK. Plant growth promoting potential of endophytic bacteria isolated from Piper nigrum. Plant Growth Regul 2013;71(1):1-11; http://doi.org/10.1007/ s10725-013-9802-y

17. Zhang Y, He L, Chen Z, Wang Q, Qian M, Sheng X. Characterization of ACC deaminase-producing endophytic bacteria isolated from copper-tolerant plants and their potential in promoting the growth and copper accumulation of Brassica napus. Chemosphere 2011;83(1)5762; http://doi.org/10.1016/j.chemosphere.2011.01.041

18. Oteino N, Lally RD, Kiwanuka S, Lloyd A, Ryan D, Germaine KJ, et al. Plant growth promotion induced by phosphate solubilizing endophytic Pseudomonas isolates. Front Microbiol 2015;6:745; http:// doi.org/10.3389/fmicb.2015.00745

19. Islam R, Trivedi P, Madhaiyan M, Seshadri S, Lee G, Yang J, et al. Isolation, enumeration, and characterization of diazotrophic bacteria from paddy soil sample under long-term fertilizer management experiment. Biol Fertil Soils 2009;46(3):261-9; http://doi.org/10.1007/ s00374-009-0425-4

20. Jayakumar A, Krishna A, Mohan M, Nair IC, Radhakrishnan EK. Plant growth enhancement, disease resistance, and elemental modulatory effects of plant probiotic endophytic Bacillus sp. Fcl1. Probiotics Antimicrob Proteins 2018;11(2):526-34; http://doi.org/10.1007/s12602-018-9417-8

21. Tan D, Fu L, Han B, Sun X, Zheng P, Zhang J. Identification of an endophytic antifungal bacterial strain isolated from the rubber tree and its application in the biological control of banana fusarium wilt. PLoS One 2015;10(7):e0131974; http://doi.org/10.1371/journal. pone. 0131974

22. Coombs JT, Franco CM. Isolation and identification of actinobacteria from surface-sterilized wheat roots. Appl Environ Microbiol 2003;69(9):5603-8.

23. Dashti AA, Jadaon MM, Abdulsamad AM, Dashti HM. Heat treatment of bacteria: a simple method of DNA extraction for molecular techniques. Kuwait Med J 2009;41:117-22.

24. Lane DJ. 16S/23S rRNA sequencing. In: Stackebrandt E, Goodfellow M (eds.). Nucleic Acid Techniques in Bacterial Systematic, John Wiley and Sons, New York, NY, pp 115-75, 1991.

25. Saitou N, Nei M. The neighbor-joining method: a new method for reconstructing phylogenetic trees. Mol Biol Evol 1987;4:406-25.

26. Felsenstein J. Confidence limits on phylogenies: an approach using the bootstrap. Evolution. 1985;39:783-91.

27. Tamura K, Nei M, Kumar S. Prospects for inferring very large phylogenies by using the neighbor-joining method. Proc Natl Acad Sci USA 2004;101:11030-5.

28. Kumar S, Stecher G, Li M, Knyaz C, Tamura K. MEGA X: molecular evolutionary genetics analysis across computing platforms. Mol Biol Evol 2018;35:1547-9.

29. Sarwar M, Kremer RJ. Determination of bacterially derived auxins using a microplate method. Lett Appl Microbiol 1995;20:282-5.

30. Kuklinsky-Sobral J, Araújo WL, Mendes R, Geraldi IO, PizziraniKleiner AA, Azevedo JL. Isolation and characterization of soybeanassociated bacteria and their potential for plant growth promotion. Environ Microbiol 2004;6:1244-51.

31. Mehta S, Nautiyal CS. An efficient method for qualitative screening of phosphate-solubilizing bacteria. Curr Microbiol 2001;43(1):51-6.

32. Bashan Y, Holguin G, Lifshitz R. Isolation and characterization of plant growth-promoting rhizobacteria. In: Glick BR, Thompson JE (eds.). Methods in Plant Molecular Biology and Biotechnology, CRC Press, Boca Raton, FL, pp 331-45, 1993.

33. Schwyn B, Neilands JB. Universal chemical assay for the detection and determination of siderophores. Anal Biochem 1987;160:45-6.

34. Egamberdieva D, Kucharova Z, Davranov K, Berg G, Makarova $\mathrm{N}$, Azarova T, et al. Bacteria able to control foot and root rot and to promote growth of cucumber in salinated soils. Biol Fertil Soils 2011;47:197-205.

35. Egamberdieva D, Shurigin V, Gopalakrishnan S, Sharma R. Microbial strategies for the improvement of legume production in hostile environments. In: Azooz MM, Ahmad P (eds.). Legumes under environmental stress: yield, improvement and adaptations, John Wiley \& Sons Ltd, Chichester, UK, pp 133-44, 2015; http://doi. org/10.1002/9781118917091.ch9

36. Gamez R, Cardinale M, Montes M, Ramirez S, Schnell S, Rodriguez F. Screening, plant growth promotion and root colonization pattern of two rhizobacteria (Pseudomonas fluorescens Ps006 and Bacillus amyloliquefaciens Bs006) on banana cv. Williams (Musa acuminate Colla). Microbiol Res 2019;220:12-20.

37. Park YG, Mun BG, Kang SM, Hussain A, Shahzad R, Seo CW, et al Bacillus aryabhattai SRB02 tolerates oxidative and nitrosative stress and promotes the growth of soybean by modulating the production of phytohormones. PLoS One 2017;12(3):e0173203; http://doi. org/10.1371/journal.pone.0173203

38. Xu JX, Li ZY, Lv X, Yan H, Zhou GY, Cao LX, et al. Isolation and characterization of Bacillus subtilis strain 1-L-29, an endophytic bacteria from Camellia oleifera with antimicrobial activity and efficient plant-root colonization. PLoS One 2020;15(4):e0232096; http://doi.org/10.1371/journal.pone.0232096 

growth-promoting properties 2022;10(01):45-53

39. Falcao LL, Silva-Werneck JO, Vilarinho BR, da Silva JP, Pomella AWV, Marcellino LH. Antimicrobial and plant growth-promoting properties of the cacao endophyte Bacillus subtilis ALB629. J Appl Microbiol 2014;116(6):1584-92; http://doi.org/10.1111/jam.12485

40. Bolivar-Anillo HJ, González-Rodríguez VE, Cantoral JM, GarcíaSánchez D, Collado IG, Garrido C. Endophytic bacteria Bacillus subtilis, isolated from Zea mays, as potential biocontrol agent against Botrytis cinerea. Biology 2021;10:492; http://doi.org/10.3390/ biology 10060492

41. Contreras-Pérez M, Hernández-Salmerón J, Rojas-Solís D, RochaGranados C, del Carmen Orozco-Mosqueda M, Parra-Cota FI, et al. Draft genome analysis of the endophyte, Bacillus toyonensis COPE52, a blueberry (Vaccinium spp. var. Biloxi) growth-promoting bacterium. 3 Biotech 2019;9(10):370; http://doi.org/10.1007/s13205-019-1911-5

42. Zhou N, Zhao S, Tian CY. Effect of halotolerant rhizobacteria isolated from halophytes on the growth of sugar beet (Beta vulgaris L.) under salt stress. FEMS Microbiol Lett 2017;364(11):fnx091; http://doi. org/10.1093/femsle/fnx091

43. Leghari SJ, Wahocho NA, Laghari GM, Laghari AH, Bhabhan GM, Talpur KA, et al. Role of nitrogen for plant growth and development: a review. Adv Environ Biol 2016;10(9):209-19.

44. Galloway JN, Cowling EB. Reactive nitrogen and the world: 200 years of change. J Hum Environ 2002;31(2):64-71; http://doi. org/10.1579/0044-7447-31.2.64

45. Muangthong A, Youpensuk S, Rerkasem B. Isolation and characterisation of endophytic nitrogen fixing bacteria in sugarcane. Trop Life Sci Res 2015;26(1):41-51.
46. Yadav AN. Biodiversity and biotechnological applications of hostspecific endophytic fungi for sustainable agriculture and allied sectors. Acta Sci Microbiol 2018;1:44; http://doi.org/10.31080/ ASMI.2018.01.0044

47. Gao FK, Dai CC, Liu XZ. Mechanisms of fungal endophytes in plant protection against pathogens. Afr J Microbiol Res 2010;4:1346-51.

48. Gao D, Tao Y. Current molecular biologic techniques for characterizing environmental microbial community. Front Environ Sci Eng 2012;6:82-97; http://doi.org/10.1007/s11783-011-0306-6

49. Glick BR, Penrose DM, Li J. A model for the lowering of plant ethylene concentrations by plant growth-promoting bacteria. J Theor Biol 1998;190:63-8; http://doi.org/10.1006/jtbi.1997.0532

50. Rajkumar M, Ae N, Prasad MNV, Freitas H. Potential of siderophoreproducing bacteria for improving heavy metal phytoextraction. Trends Biotechnol 2010;28:142-9; http://doi.org/10.1016/j. tibtech.2009.12.002

\section{How to cite this article:}

Shurigin V, Alikulov B, Davranov K, Ismailov Z. Bacterial endophytes from halophyte black saxaul (Haloxylon aphyllum Minkw.) and their plant growth-promoting properties. J Appl Biol Biotech 2022; 10(01):45-53. 